\title{
Short-term movements and habitat preferences of sailfish, Istiophorus platypterus (Istiophoridae), along the southeast coast of Brazil
}

\author{
Bruno L. Mourato ${ }^{*}$, Felipe Carvalho ${ }^{2}$, Michael Musyl ${ }^{3}$, Alberto Amorim ${ }^{4}$, \\ Jose C. Pacheco ${ }^{5}$, Humberto Hazin ${ }^{5}$ and Fábio Hazin ${ }^{5}$
}

Pop-up satellite archival tags (PSATs) were deployed on four sailfish, Istiophorus platypterus, in the coastal waters of Rio de Janeiro State in southeast Brazil during January and February of 2009 (sailfish I and II) and between November 2010 and January 2011 (sailfish III and IV). The total number of days monitored (i.e., time that the tags remained attached) were 12 (sailfish I), 51 (sailfish II), 16 (sailfish III) and 43 days (sailfish IV). The results indicate a clear pattern of vertical habitat utilization with the majority of the time spent concentrated near the uniform sea surface layer occupying a relatively narrow temperature range. Despite the clear preference for epipelagic surface waters, sailfish regularly undertook vertical excursions into deeper waters $(>50 \mathrm{~m}$ ) within three to six hour intervals. "Most Probable Tracks" (estimated from raw geolocations using the state-space Kalman filter model) and linear displacements suggested that tagged sailfish did not move significant distances from the tagging site. In brief, our report provides information regarding the biology of sailfish in the southwestern Atlantic and how vertical distributions during the day and night are influenced by water temperature and how this information can improve sailfish stock assessments in southwestern Atlantic Ocean.

Quatro exemplares de agulhão-vela foram marcados com marcas eletrônicas monitoradas por satélite ('Pop-up satellite archival tags - PSATs') nas águas costeiras do Rio de Janeiro, sudeste do Brasil, durante janeiro e fevereiro de 2009 (agulhão-vela I e II) e entre novembro de 2010 e janeiro de 2011 (agulhão-vela III e IV). O número total de dias monitorados (ou seja, o tempo que as marcas permaneceram implantadas nos peixes) foram 12 (agulhão-vela I), 51 (agulhão-vela II), 16 (agulhão-vela III) e 43 dias (agulhão-vela IV). Os resultados demonstram um padrão claro de utilização do hábitat com a maior parte do tempo despendido predominantemente próximo à superfície do mar ocupando águas com uma faixa de temperatura restrita. Apesar da preferência por águas superficiais, os agulhões frequentemente realizaram mergulhos para águas mais profundas ( $c a .>50 \mathrm{~m})$ em intervalos de três a seis horas. A "rota mais provável" estimada a partir dos dados brutos de geolocalização e o modelo "State-Space Kalman Filter' sugerem que os agulhões marcados não realizaram migrações significativas a partir do local de marcação. Em resumo, nossos resultados apresentam informações sobre a biologia da espécie no Atlântico Sudoeste e como as migrações verticais durante o dia e a noite são influenciadas pela temperatura da água e como essa informação pode auxiliar as avaliações de estoques de agulhão-vela no sudoeste do Atlântico.

Key words: Delta SST, Horizontal movements, Pop-up satellite archival tags (PSATs), Sailfish, Southwest Atlantic, Vertical habitat.

\footnotetext{
${ }^{1}$ Universidade Federal de São Paulo, Departamento de Ciências do Mar. Av. Almirante Saldanha da Gama, 89, 11030-400 Santos, SP, Brazil. mourato.br@gmail.com

${ }^{2}$ University of Florida, Program of Fisheries and Aquatic Sciences, School of Forest Resources and Conservation.7922 NW 71 ${ }^{\text {st }}$, Gainesville, FL 32653, USA. fcorreia@ufl.edu

${ }^{3}$ Pelagic Research Group LLC. P.O. Box 10243. Honolulu, HI 96816, USA. michael.musyl@gmail.com

${ }^{4}$ Instituto de Pesca - SAA-SP. Avenida Bartolomeu de Gusmão, 192, 11030-906 Santos, SP. prof.albertoamorim@gmail.com

${ }^{5}$ Universidade Federal Rural de Pernambuco, Departamento de Pesca e Aquicultura, Laboratório de Oceanografia Pesqueira. Rua Dom

Manoel de Medeiros, s/n - Dois Irmãos, 52171-900 Recife, PE, Brazil. fhvhazin@terra.com.br
} 


\section{Introduction}

In the Atlantic Ocean, sailfish Istiophorus platypterus (Shaw, 1792) are widely distributed in subtropical and tropical waters and are occasionally found in temperate waters, as well as the Mediterranean Sea. Based on commercial catch data, the geographical limits for the species' distribution is approximately $40^{\circ} \mathrm{N}$ in the western North Atlantic, $50^{\circ} \mathrm{N}$ in the eastern North Atlantic, $40^{\circ} \mathrm{S}$ in the western and eastern South Atlantic (Beardsley et al., 1975; Nakamura, 1985).

Sailfish are a very important resource for various coastal and artisanal fisheries in the Caribbean, as well as for recreational fisheries in the USA, Venezuela, Brazil, and several Caribbean countries (Peel et al., 2003). Sailfish are caught as bycatch in most commercial longline fisheries targeting tunas (Thunnus spp.) and swordfish (Xiphias gladius Linnaeus, 1758) throughout the Atlantic Ocean (Restrepo et al., 2003).

The first electronic tagging study on sailfish was conducted off the east coast of Florida (USA) and sought to assess the post-release mortality of eight sailfish (Jolley \& Irby, 1979). The advent of fishery independent pop-up satellite archival tags (PSATs) in the late 1990s, however, provided a new tool to research the movements of large pelagics, including sailfish. The first experiment using PSATs on sailfish was conducted in the Gulf of Arabia (Hoolihan, 2004). Prince \& Goodyear (2006) also deployed pop-up tags on sailfish in the Northwestern Atlantic and in the Eastern Central Pacific to assess the vertical distribution of this species. Hoolihan \& Luo (2007) tagged 18 sailfish with pop-up tags which provided detailed information regarding summer residence patterns in the Gulf of Arabia.

Studies of post-release mortality for sailfish using pop-up tags were later conducted for the pelagic longline fishery in the Gulf of Mexico (Kerstetter \& Graves, 2008). More recently, to address factors to improve regional stock assessments and examine vertical swimming speeds, Hoolihan et al. (2009, 2011) and Kerstetter et al. (2011) provided detailed information regarding the vertical movements of sailfish in the western North Atlantic and eastern Pacific.

In the most recent stock assessment of sailfish in the Atlantic, using data up to 2008, results indicated a decline in biomass, particularly in the eastern Atlantic. The results were interpreted with considerable caution due to data deficiencies and the resulting uncertainty in the assessment (ICCAT, 2009). In order to reduce the uncertainty involved in the stock assessment, the International Commission for the Conservation of Atlantic Tunas (ICCAT) recognized the necessity to better understand the geographic distribution of sailfish, including: (1) identifying main areas of occurrence for different size classes, (2) understanding migration patterns, and (3) determining the influence of environmental factors on catch rates and movements.

In this context, PSATs were deployed on sailfish caught off the southeast Brazilian coast to better understand patterns of habitat use and their correlation with the environment; including the relationship of diel vertical behavior to water temperature.

\section{Material and Methods}

PSATs (Wildlife Computers Inc; Redmond, WA, USA, model MK10 PAT tags) were deployed on four adult sailfish in the coastal waters of Rio de Janeiro State, Southeast Brazil, during January and February of 2009 and between November 2010 and January 2011 (Table 1). Deployment of pop-up tags was conducted from recreational fishing vessels using standard trolling gear with natural bait and titanium circle hooks in order to increase the chances of survival of tagged fish. Once fish were hooked and wired close to the boat, the tag was deployed. The tagging target area was a little below the base of the dorsal fin, between the interneural and neural spines (Musyl \& McNaughton, 2007). The PSAT tags were affixed by harpoon equipped with a stainless steel tag applicator tip modified to be driven $c a .5-7 \mathrm{~cm}$ into the dorsal musculature. Prior to release, individual weights were estimated. The tags' ca.16-20 cm monofilament (120\# breaking strength) tethers were constructed using stainless steel crimps (matched to the diameter of the monofilament) which terminated with surgical grade nylon tag heads augmented with flopper blades (Musyl \& McNaughton, 2007). To alleviate torque and precession of the tag head, a stainless steel swivel (Sampo, Daly city, California, USA) was placed about halfway up the length of the tether.

The tags were programmed to record depth, temperature, and light intensity every 60 seconds. Depth and temperature records were compiled into histograms at 3-hour (for sailfish I and II) and 6-hour intervals (for sailfish III and IV). Minimum and maximum temperature bins (12 bins total) were programmed to sample temperatures $\geq 12^{\circ} \mathrm{C}$ and $\leq 30^{\circ} \mathrm{C}$, while depth bins (12 bins total) were programmed to sample the minimum depth of $\leq 1 \mathrm{~m}$ (or 0 ) and maximum depth up to 300 $\mathrm{m}$. These bins were chosen based on the vertical movement behavior of sailfish tagged in other geographical areas (e.g., Hoolihan, 2004; Prince \& Goodyear, 2006). The pop-up tags were programmed for deployment periods of 60 days (sailfish I and II) and 140 days (sailfish III and IV).

Light intensity records were post-processed using the

Table 1. Summary details for setup, release, pop-up and data received from pop-up satellite archival tags deployed on sailfish in Brazil.

\begin{tabular}{|c|c|c|c|c|c|c|c|c|c|}
\hline Sailfish ID & $\begin{array}{c}\text { Estimated } \\
\text { weight }(\mathrm{kg})\end{array}$ & Tagging date & Pop-up date & $\begin{array}{l}\text { Days at } \\
\text { liberty }\end{array}$ & $\begin{array}{c}\text { Data received } \\
(\%)\end{array}$ & $\begin{array}{c}\text { Days of } \\
\text { geolocations }\end{array}$ & $\begin{array}{c}\text { Binning } \\
\text { hours }\end{array}$ & Position tagging & Pop-up position \\
\hline $\mathrm{I}$ & $25-30$ & 1-Feb-09 & 16-Feb-09 & 12 & 82 & 12 & 3 & $23^{\circ} 28^{\prime} \mathrm{S} / 42^{\circ} 26^{\prime} \mathrm{W}$ & $25^{\circ} 31^{\prime} \mathrm{S} / 41^{\circ} 39^{\prime} \mathrm{W}$ \\
\hline II & 20 & 26-Jan-09 & 16-Mar-09 & 51 & 75 & 21 & 3 & $23^{\circ} 19^{\prime} \mathrm{S} / 42^{\circ} 18^{\prime} \mathrm{W}$ & $24^{\circ} 22^{\prime} \mathrm{S} / 42^{\circ} 05^{\prime} \mathrm{W}$ \\
\hline III & 20 & 21-Nov-10 & 5-Dec-10 & 16 & 46 & 16 & 6 & $23^{\circ} 36^{\prime} \mathrm{S} / 42^{\circ} 41^{\prime} \mathrm{W}$ & $24^{\circ} 15^{\prime} \mathrm{S} / 43^{\circ} 50^{\prime} \mathrm{W}$ \\
\hline IV & $30-35$ & 11-Dec-10 & 24-Jan-11 & 43 & 12.5 & 12 & 6 & $23^{\circ} 28^{\prime} \mathrm{S} / 42^{\circ} 27^{\prime} \mathrm{W}$ & $25^{\circ} 38^{\prime} \mathrm{S} / 40^{\circ} 44^{\prime} \mathrm{W}$ \\
\hline
\end{tabular}


global positioning software WC-GPE (Wildlife Computers, Redmond, WA, USA) to provide daily raw geolocations (i.e., unfiltered and uncorrected estimates) of tagged fish for each day at-liberty. First, we applied the Kalman Filter State-Space Model augmented with SST (UKFSST; Nielsen et al., 2006) to predict Most Probable Tracks (MPTs) of tagged fish. However, the UKFSST model did not achieve convergence. Reasons for the non-convergence might be related to the lack of sufficient SST gradient in satellite derived SST fields and/or missing data (due to clouds and limitations in spatial coverage). For this reason, we applied the regular Kalman Filter State-Space Model (KFTRACK; Sibert et al., 2003) and all models obtained convergence.

From the MPTs, daily estimated geographical positions of the tagged fish were used to estimate the times of local sunrise, sunset, and noon (using standard astronomical formulae, Duffett-Smith, 1988) from which the temperature and depth data were assigned to three distinct periods (day, night, and crepuscular transitions) (Musyl et al., 2011a). Two of the tags were programmed to compile data into histograms at 3-hour intervals (e.g., sailfish I and II). Converting the data from these tags to match the interval sampling periods of the other two tags would necessitate the loss of data and resolution. By examining and parsing the data for transition periods (e.g., $5 \mathrm{am}$ to 8 am and from $5 \mathrm{pm}$ to $8 \mathrm{pm}$ ), this allowed us to examine the data at a much finer scale of resolution. For sailfish III and IV, however, this procedure was not needed since tags were programmed to compile data into histograms at 6-hour intervals, requiring the assignment of only night and day periods. The time-at-depth and time-at-temperature (day, night, transition) data were aggregated into bins and were subsequently expressed as a proportion of the total time for each fish. One-sample Shapiro tests indicated that data distributions were non-normally distributed $(p<0.05)$. Runs test (Zar, 1996) indicated the time series of temperature and depth data were randomly distributed. All statistical tests were performed at the $\mathrm{p}<0.05$ level of significance.

We also evaluated the temperature readings of each tagged fish expressed as differences from average daily sea surface temperature ( $\Delta$ SST, Brill et al., 1993, Musyl et al., 2011a). This information can be especially useful to correct catch per unit effort data for differences in gear vulnerability (i.e., Habitat Based Models; Hinton \& Nakano, 1996) and for comparing tagging results between different regions. Average daily sea surface temperature (SST) was calculated by extracting the temperatures from Profile of Depth and Temperature data (PDT), contained in the tags' data products, where depth was $\leq 10 \mathrm{~m}$. $\Delta \mathrm{SST}$ values were then calculated by subtracting the temperature of each PDT observation from the average daily sea surface temperature and the absolute differences were tabulated as cumulative percentages.

\section{Results}

All PSATs popped off prematurely and began transmitting data before the expected dates of detachment (60 or 140 days after deployment). The total number of days monitored were 12 (sailfish I), 51 (sailfish II), 16 (sailfish III) and 43 days (sailfish IV). However, the total percentage of data successfully transmitted through the ARGOS satellite system was $82 \%, 75 \%, 46 \%$, and $12.5 \%$ of the total archived data for tags I, II, III, and IV, respectively (Table 1). The geographical positions (raw geolocations) were obtained for 63 days in total (Table 1).

The results indicate a clear pattern of near surface habitat utilization in sailfish, with the majority of the time spent near the sea surface within a relatively narrow temperature range. Sailfish I spent $67 \%, 90 \%$, and $81 \%$ of its time between the surface and $10 \mathrm{~m}$, during day, night, and transition periods, respectively, while sailfish II spent $72 \%, 69 \%$, and $66 \%$ in the same depth stratum and periods (Fig. 1; Table 2). Sailfish III spent $73 \%$ and $64 \%$ of its time between 0 and $10 \mathrm{~m}$ during day and night periods, respectively, while sailfish IV spent $72 \%$ and $54 \%$ in the same depth stratum and periods (Fig. 1; Table 2).

Sailfish I remained in water temperatures between $25^{\circ}$ and $28^{\circ} \mathrm{C}$ for $90 \%$ of the day, $87 \%$ of the night, and $77 \%$ of the transition periods, while sailfish II remained between $25^{\circ}$ and $28^{\circ} \mathrm{C}$, for $77 \%, 73 \%$, and $74 \%$ of day, night, and transition periods, respectively (Fig. 2; Table 2). Sailfish III spent more time in cooler waters, with temperatures ranging from $24^{\circ}$ to $27^{\circ} \mathrm{C}$ for $89 \%$ and $82 \%$ of its time during day and night periods, respectively (Fig. 2; Table 2). Sailfish IV exhibited a similar behavior pattern to sailfish I and II, remaining in water temperatures between $25^{\circ}$ and $28^{\circ} \mathrm{C}$ for $90 \%$ of the day and $69 \%$ of the night periods (Fig. 2; Table 2). $\Delta$ SST calculations showed that all tagged sailfish spent the vast majority of their time in the uniform temperature surface layer, exposed to temperature changes of approximately $8^{\circ} \mathrm{C}$ from SST (Table 3).

The minimum and maximum daily temperature and depth experienced by the tracked sailfish (Fig. 3) show that sailfish I spent most of the time in waters above $20^{\circ} \mathrm{C}$ (average depth of $40 \mathrm{~m}$ ) with only two dives on February 2, 2009 to water temperatures of $16^{\circ} \mathrm{C}(120 \mathrm{~m})$ (Fig. 3). On the other hand, sailfish II experienced temperatures and depths much cooler and deeper than sailfish I, with a minimum temperature of $11.1^{\circ} \mathrm{C}$ during its deepest dive (376 m) on February 25 (Fig. 3). Sailfish III exhibited a similar behavior as sailfish I, spending most of the time in waters above $23^{\circ} \mathrm{C}$ (average depth of 40 $\mathrm{m}$ ), with two dives on November 25, 2010 to water temperatures of $20^{\circ} \mathrm{C}(120 \mathrm{~m})$ (Fig. 3). Further, the two deepest dives made by sailfish I $(c a .120 \mathrm{~m})$ were observed immediately after release. For sailfish II, the deepest observed dives reached was $376 \mathrm{~m}$, while sailfish III's deepest dive was to $112 \mathrm{~m}$. Sailfish IV, however, exhibited the deepest dive to $560 \mathrm{~m}$. Between February 25 and March 10, sailfish II experienced minimum daily temperatures notably cooler than the rest of the tracked period (Fig. 3). This may indicate that the fish moved near the edge of a cooler water mass. Also, the maximum daily depths when the fish moved into the cooler water mass were notably shallower (around $50 \mathrm{~m}$ ) in comparison to the rest of tracked period (around $100 \mathrm{~m}$ ) (Fig. 3). 
Table 2. Mean, minimum, maximum temperatures and depths with the respective standard deviation experienced by tagged sailfish during the tracked period by fish and period.

\begin{tabular}{lccccc}
\hline Period & Sailfish ID & Mean temperature & Min temperature & Max temperature & Standard Deviation \\
\hline Day & sailfish I & 25.06 & 16.30 & 27.10 & 1.85 \\
Night & sailfish I & 25.34 & 20.50 & 27.10 & 1.48 \\
Transition & sailfish I & 25.36 & 21.40 & 28.00 & 1.56 \\
Day & sailfish II & 24.16 & 14.80 & 28.60 & 2.77 \\
Night & sailfish II & 23.48 & 11.10 & 28.60 & 2.32 \\
Transition & sailfish II & 23.82 & 15.00 & 26.80 & 2.90 \\
Day & sailfish III & 24.08 & 20.10 & 26.40 & 1.15 \\
Night & sailfish III & 23.93 & 20.20 & 26.70 & 1.17 \\
Day & sailfish IV & 24.37 & 15.70 & 26.80 & 3.30 \\
Night & sailfish IV & 23.51 & 12.40 & Max depth & Standard Deviation \\
\hline Period & Sailfish ID & Mean depth & Min depth & 720 & 22.61 \\
Day & sailfish I & 21.53 & 0 & 72 & 19.49 \\
Night & sailfish I & 18.10 & 0 & 0 & 120 \\
Transition & sailfish I & 19.42 & 0 & 376 & 160 \\
Day & sailfish II & 23.72 & 0 & 96 & 21.06 \\
Night & sailfish II & 29.18 & 0 & 112 & 24.72 \\
Transition & sailfish II & 26.41 & 0 & 112 & 23.11 \\
Day & sailfish III & 24.76 & 0 & 560 & 23.91 \\
Night & sailfish III & 26.33 & 0 & & 23.63 \\
Day & sailfish IV & 23.33 & 0 & & 79.80 \\
Night & sailfish IV & 46.11 & & 0 & \\
\hline
\end{tabular}

Sailfish I

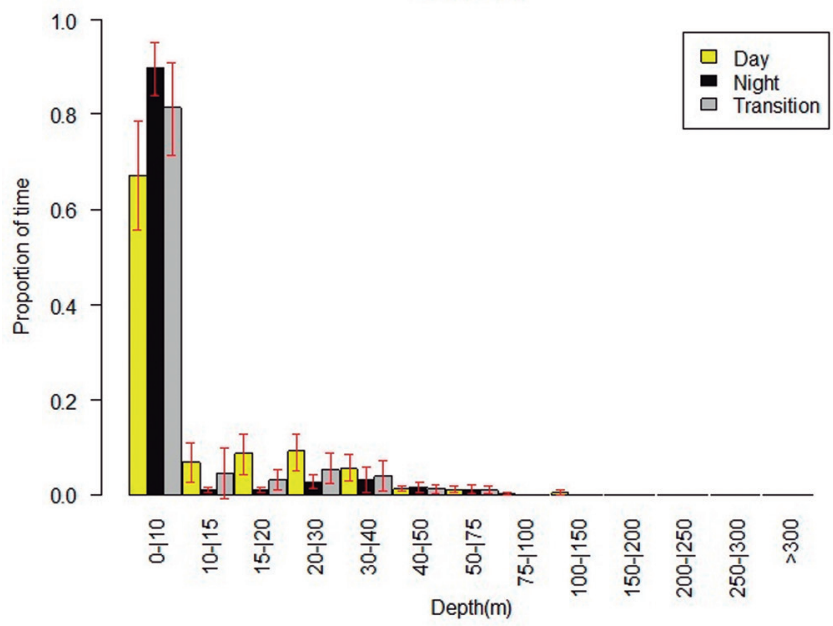

Sailfish III

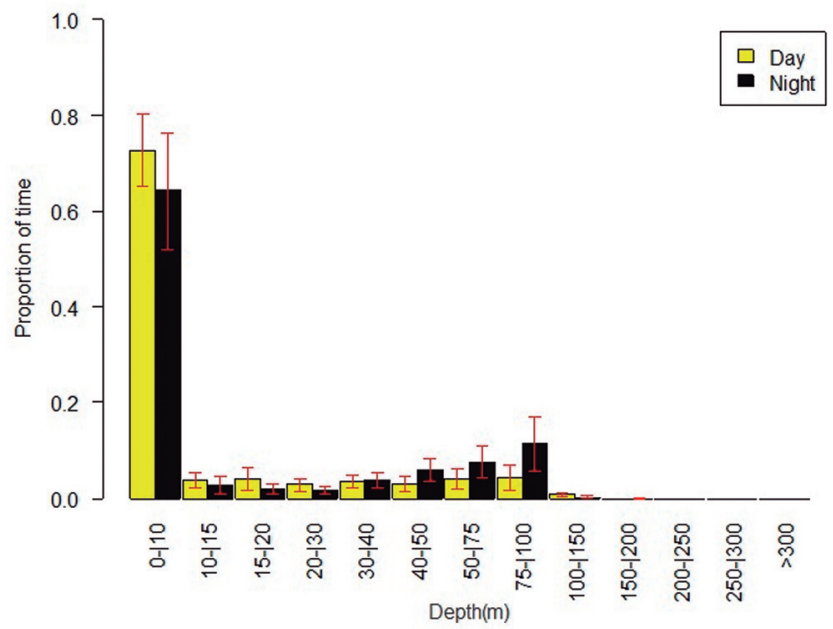

Sailfish II
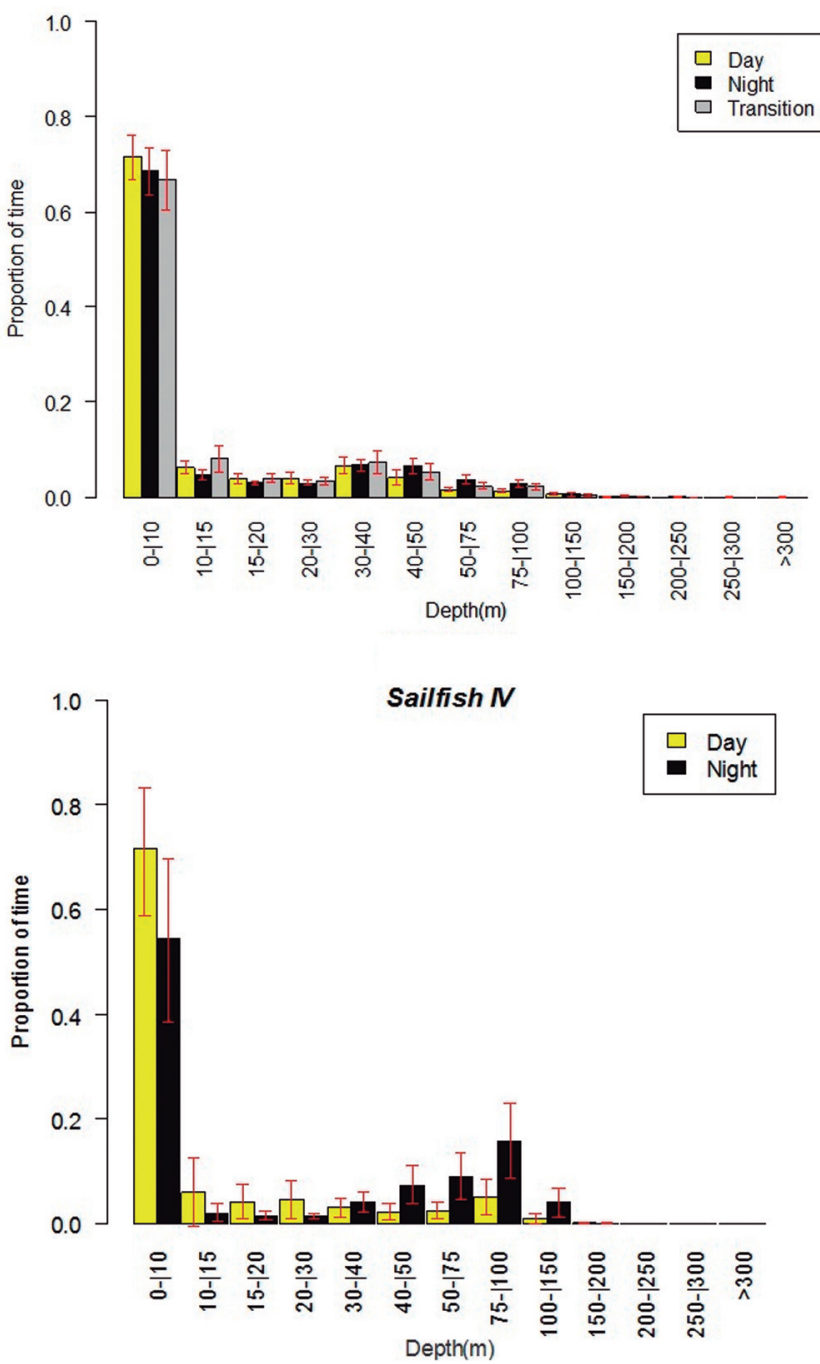

Fig. 1. Depth histograms, showing relative frequency of time spent at depth for each tagged sailfish. Error bars indicates the standard errors around mean values. 
The MPTs and straight-line distances from deployment to pop-up locations suggest that tagged sailfish did not move significant distances away from tagging locations. Movement errors for latitude and longitude estimates for the MPTs were low (longitude: ranging from 0.02 to 0.61 degrees; latitude: ranging from 0.14 to 1.91 degrees) and similar to those found in other movement studies using the KFTRACK model (Sibert et al., 2003, Musyl et al., 2011b). The errors for latitude estimates were slightly higher than longitude estimates which is generally the situation (Musyl et al., 2001, Sibert et al., 2003). Sailfish I moved in a southeastward direction away from the Brazilian coast until the $7^{\text {th }}$ day at liberty. Afterwards, it exhibited a westward movement until the pop-up event which occurred very close to the tagging site (Fig. 4). Sailfish

\section{Sailfish I}

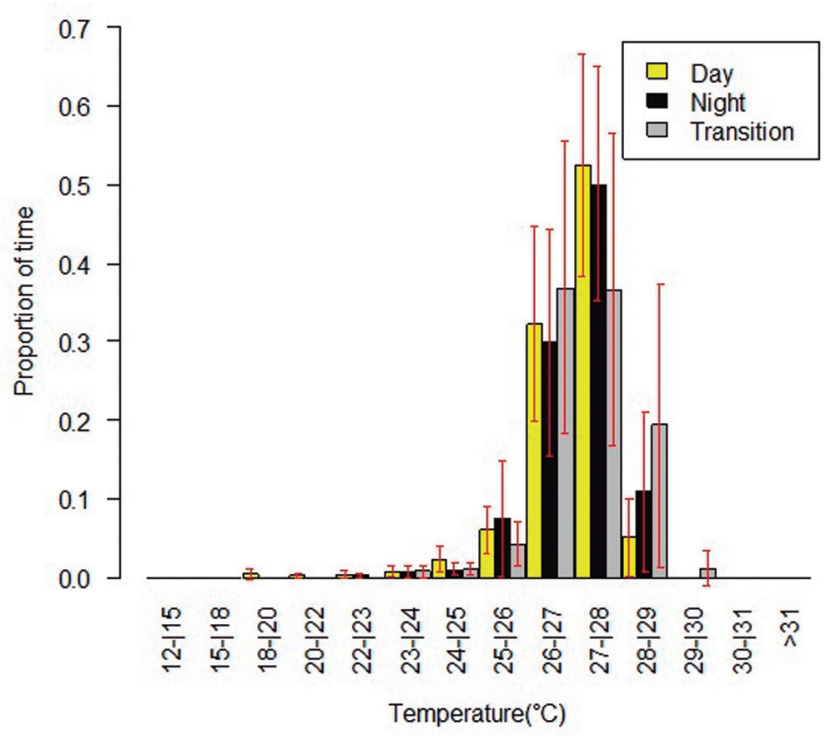

Sailfish III

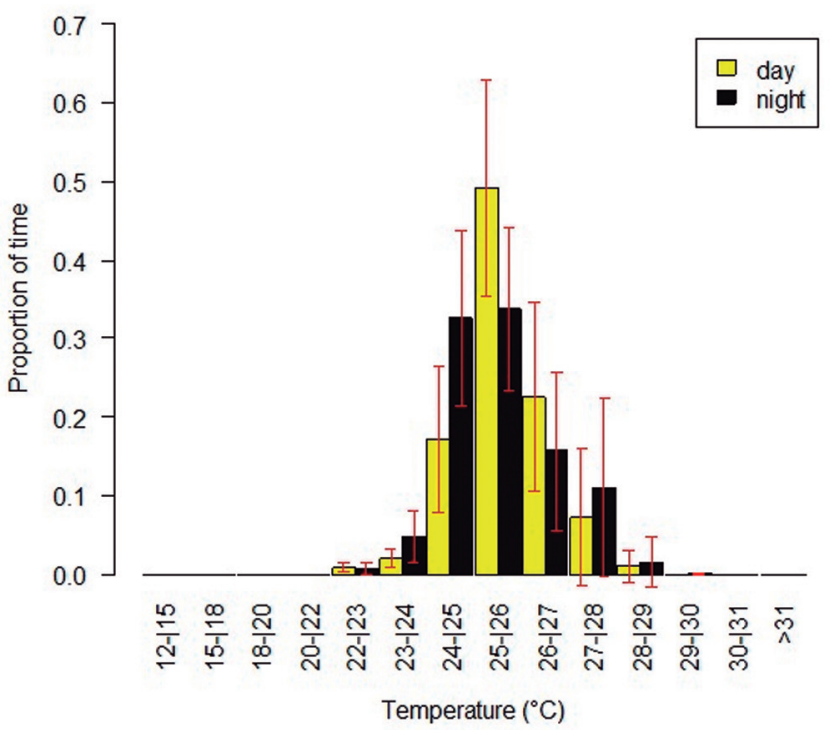

II moved southeast away from the Brazilian coast with the position of the first transmission also relatively close to the tagging site (Fig. 4). Sailfish III showed a meandering movement pattern, with the position of the first transmission, however, being relatively close to the coast (Fig. 4). Sailfish IV first moved south, then exhibited an eastward movement away from the Brazilian coast, returning towards the continent until the pop-up event (Fig. 4).

\section{Discussion}

In the present study, sailfish shed their tags prematurely, averaging around $30 \%$ of their expected programmed attachment times. The results suggest that the pop-up event
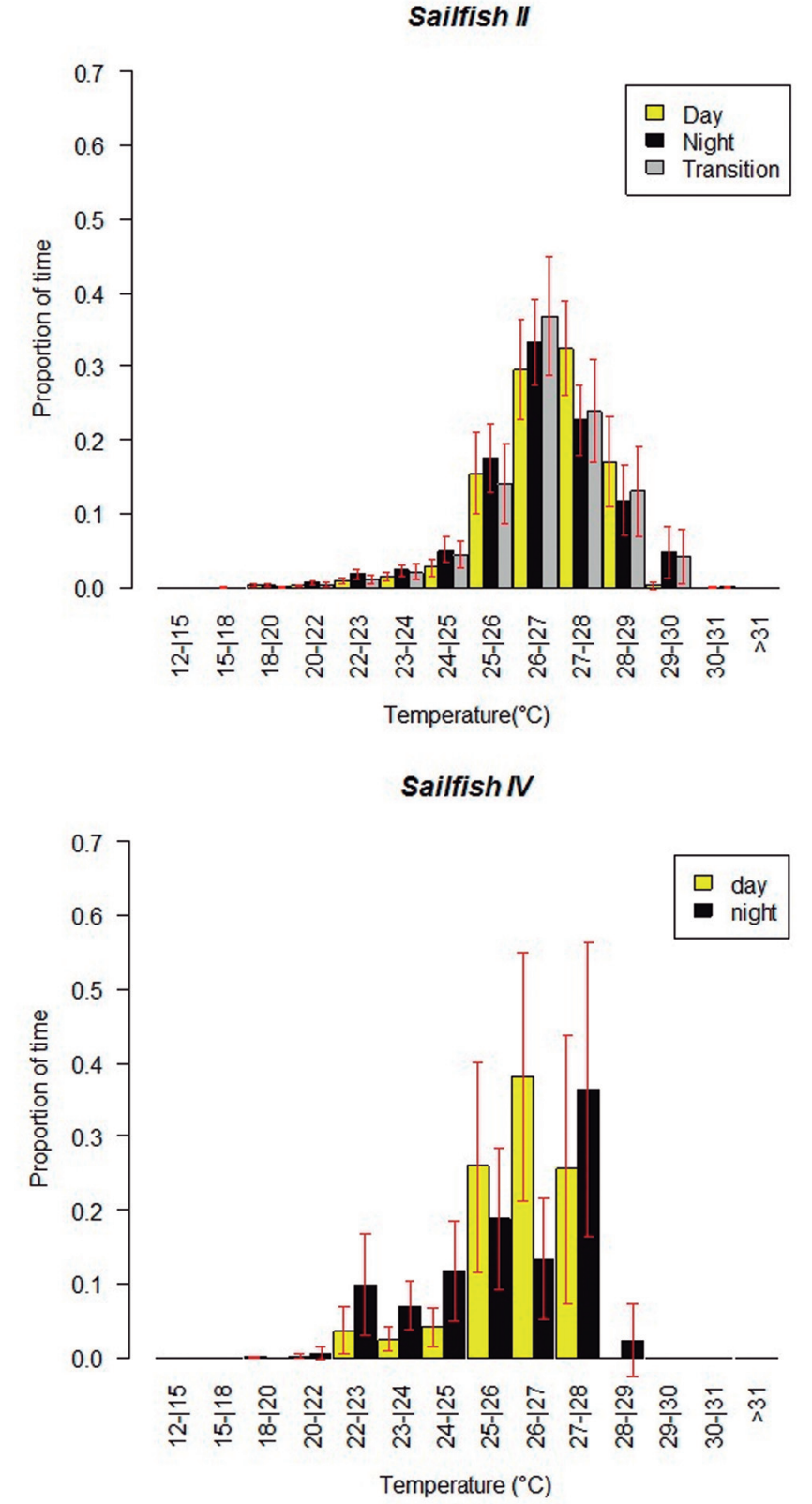

Fig. 2. Temperature histograms, showing the relative frequency of time spent at temperature for each tagged sailfish individual. Error bars indicates the standard errors around mean values. 
occurred while the fish were alive and was not attributable as a result of death followed by sinking. All tagged specimens were large enough to carry a PSAT and were released in good condition with the hooks removed before release. Moreover, estimates of post release survival also indicate that sailfish have a high survival rate after capture by pelagic longline fishing gears (Kerstetter \& Graves, 2008), which is probably even more traumatic than the recreational fishing gear used in the present study.

According to Musyl et al. (2011b), probable causes of early detachment and low tag retention rates might include infections and tissue necrosis around the tagging site and increased drag as a result of biofouling. Saifish are inhabitants of the photic zone and animals inhabiting this zone generally are exposed to significantly more fouling and infectious organisms than deeper diving animals and consequently have significantly lower tag retention rates. Despite early tag detachment, our results indicate that the tags carried by sailfish III and IV did not successfully transmit appreciable portions of their archived data through ARGOS (see Table 1). Factor which might influence low data transmission rates to ARGOS are not well understood but biofouling is thought to be a factor (Musyl et al., 2011b).

\section{Vertical distribution}

The present results showed a marked preference of tagged sailfish to occupy the upper $10 \mathrm{~m}$ of the water column during all times of day. This pattern is consistent with previous studies using acoustic and pop-up tags on sailfish in other parts of world (Hoolihan, 2004; Hoolihan \& Luo, 2007; Prince \& Goodyear, 2006; Kerstetter \& Graves, 2008; Kerstetter et al., 2011; Chiang et al., 2011). The tagged sailfish also seemed to have a rather narrow temperature distribution. Our results showed a marked preference of sailfish for the warmer waters
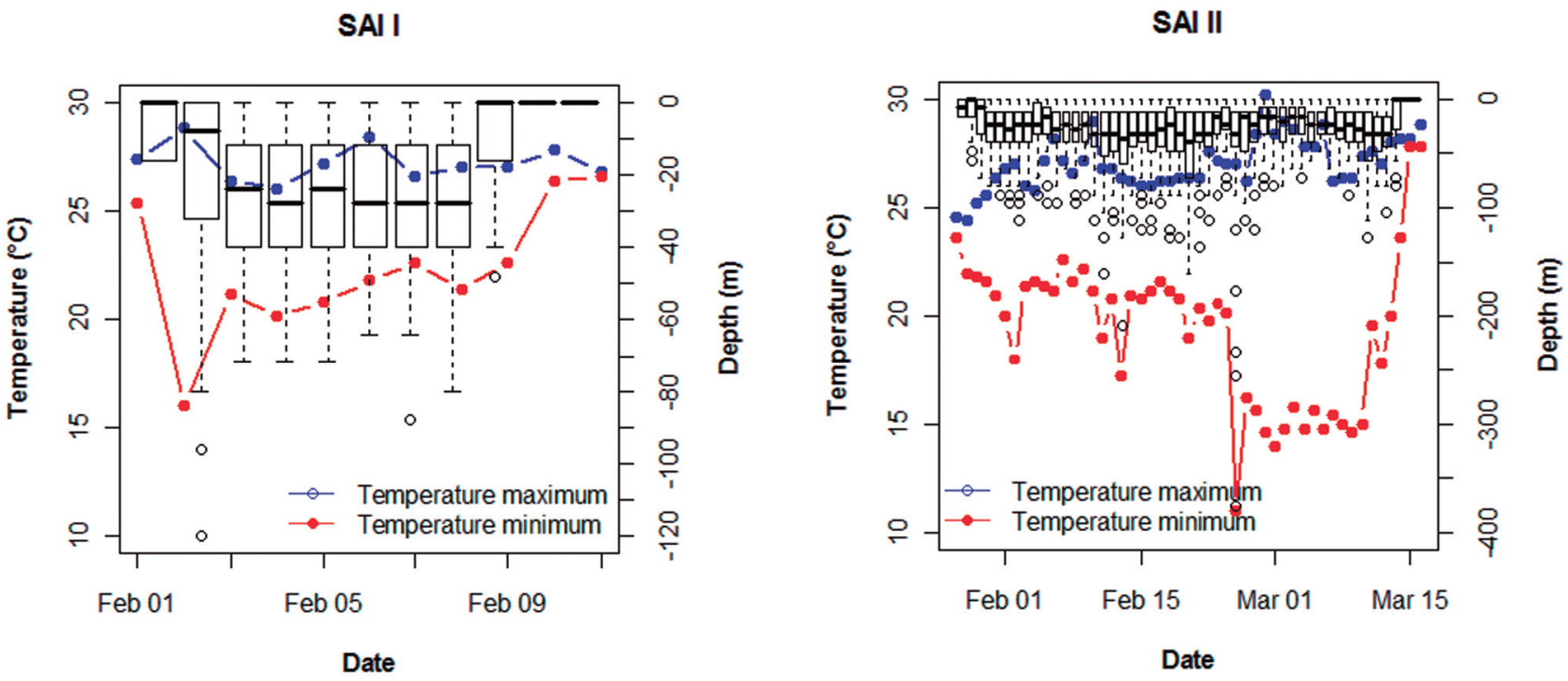

\section{SAI III}

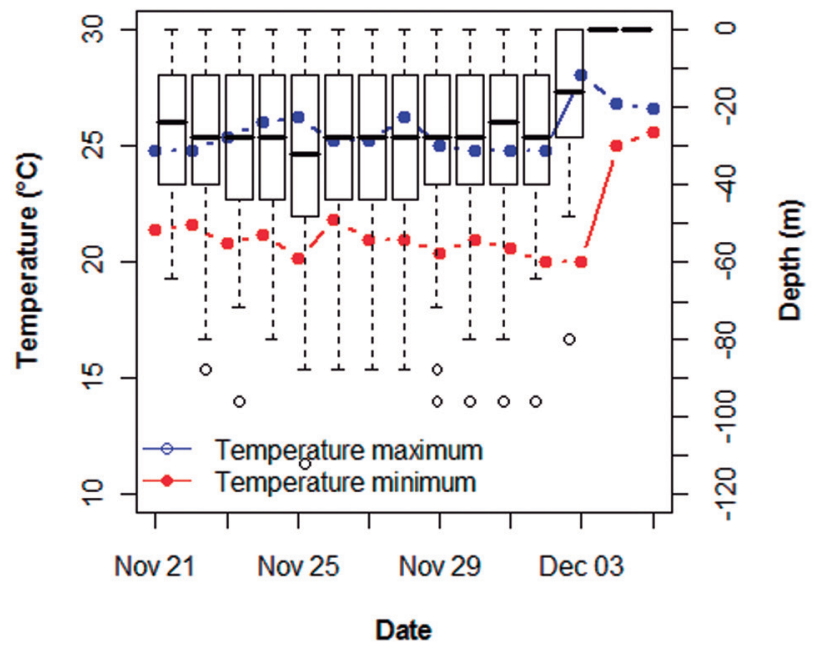

Fig. 3. Minimum and maximum daily temperature and depth experienced by sailfish I, II and III. Box-plots represent the depths experienced by tagged sailfish. 
Table 3. Cumulative percentage of temperature readings from pop-up satellite archival tags deployed on sailfish in the southeast coast of Brazil expressed as differences from daily calculated sea surface temperature $\Delta \mathrm{SST}\left({ }^{\circ} \mathrm{C}\right)$ by day and night period (transition period was excluded of this analysis).

\begin{tabular}{|c|c|c|c|c|c|c|c|c|c|c|}
\hline \multirow{2}{*}{ SAILFISH ID } & \multicolumn{10}{|c|}{$\Delta \mathrm{SST}\left({ }^{\circ} \mathrm{C}\right)$} \\
\hline & 0 & -1 & -2 & -3 & -4 & -5 & -6 & -7 & -8 & $<-9$ \\
\hline \multicolumn{11}{|c|}{ Day } \\
\hline sailfish I & 11.54 & 53.53 & 68.59 & 83.97 & 93.59 & 96.15 & 97.44 & 98.08 & 98.08 & 100 \\
\hline sailfish II & 9.49 & 39.83 & 55.50 & 66.72 & 75.83 & 79.74 & 83.21 & 86.82 & 90.44 & 100 \\
\hline sailfish III & 6.90 & 53.88 & 87.93 & 95.69 & 98.71 & 100 & 100 & 100 & 100 & 100 \\
\hline sailfish IV & 11.98 & 55.73 & 69.27 & 82.29 & 88.54 & 92.19 & 95.83 & 96.88 & 96.88 & 100 \\
\hline \multicolumn{11}{|c|}{ Night } \\
\hline sailfish I & 5.00 & 51.56 & 66.88 & 82.50 & 94.38 & 98.13 & 100 & 100 & 100 & 100 \\
\hline sailfish II & 4.61 & 34.62 & 49.84 & 61.92 & 70.89 & 76.40 & 79.93 & 83.72 & 87.09 & 100 \\
\hline sailfish III & 6.67 & 45.00 & 82.92 & 91.67 & 95.83 & 98.33 & 99.58 & 100 & 100 & 100 \\
\hline sailfish IV & 5.56 & 38.89 & 53.47 & 65.28 & 73.61 & 79.86 & 84.03 & 88.19 & 89.58 & 100 \\
\hline
\end{tabular}

of the mixed layer, with all sailfish having spent less than $3 \%$ of their time in waters colder than $8^{\circ} \mathrm{C}$ relative to the warmest water available. Moreover, our study suggests that thermal habitat for sailfish near Brazil may be adequately described by two dimensions (this species spend most of their time in the warmest available water).

Other studies have also shown a restricted temperature range for the species in the Pacific and Atlantic Oceans (Prince \& Goodyear, 2006; Chiang et al., 2011; Hoolihan et al., 2011; Kerstetter et al., 2011). The clear preference of sailfish for warm water near the surface is shared by other istiophorid billfish as well, including black marlin in the Coral Sea (Pepperell \& Davis 1999; Gunn et al., 2003), Atlantic blue marlin (Graves et al., 2002, Kerstetter et al., 2003, Prince \& Goodyear 2006, Goodyear et al., 2008), Pacific blue marlin (Holland et al., 1990, Block et al., 1992), and striped marlin (Holts \& Bedford, 1990; Brill et al., 1993).

The present results also showed that the tagged sailfish did not exhibit a high degree of depth and temperature variability in their movements. This pattern is consistent with the results reported for sailfish in Gulf of Arabia by Hoolihan \& Luo (2007). On the other hand, Goodyear et al. (2008), analyzing a database of 51 pop-up tags deployed in Atlantic

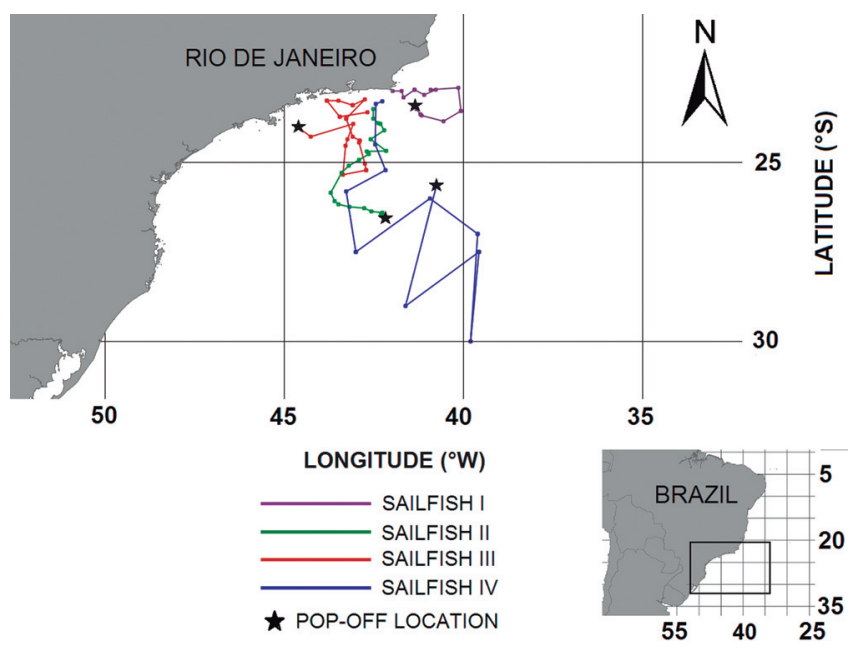

Fig. 4. Most-probable tracks for sailfish I, II, III, and IV fitted with Kalman Filter State-Space Model. blue marlin, found a complex vertical behavior for this species. Musyl et al. (2003) also reported complex habitat utilization patterns for different sized bigeye tuna in the North Pacific Ocean with clear behavioral differences between night and day and for differences based on proximity to FADs, seamounts and open ocean. In this study, no evidence of distinct diel patterns in depth and temperature preferences were observed. However, given the limited temporal and spatial coverage of tags and the high level of missing data and individual behavior shown in many tagging studies (Musyl et al., 2003, 2011a), these results must be interpreted with caution.

Although the majority of the time spent by sailfish was restricted to warmer waters near the surface, the data showed that this species is capable of making frequent deep dives exceeding 50 and $100 \mathrm{~m}$, with the deepest dive exceeding 500 $\mathrm{m}$. Vertical movement patterns in large pelagic fish have been reported to be very complex, reflecting behaviors such as foraging, thermoregulation, or predator avoidance (Brill \& Lutcavage, 2001). The sailfish dives observed in the present study may be related to an opportunistic feeding behavior. Although the PSAT technology does not allow for the direct study of feeding events, two particularities of sailfish biology seem to support this hypothesis. The first, of a physiological and anatomical nature, is related to the fact that sailfish, like other istiophorids, have a specialized eye/ brain heater organ, allowing for deeper dives (Block, 1986) on an ephemeral basis. The second is related to stomach content analyses conducted in the same region, which show the presence of mesopelagic species in their diet (Vaske-Júnior et al., 2004, Vaske-Júnior, 2005). Analysis of high resolution tracking data are still needed in order to better understand the vertical movements of the species at a finer scale.

The results of the present study suggest that ambient water temperature may be one of the dominant factors affecting the vertical distribution of the species. Sailfish II moved between two water masses with distinct thermal profiles and mixed layer depths (MLD). But after entering into cooler water, the fish restricted its dives to $<50 \mathrm{~m}$ without exposing itself to cooler waters; consistent with the limitation of vertical movements by the $c a .8^{\circ} \mathrm{C}$ relative change in water temperature with depth. 
This change in behavior may be related to the oceanographic conditions that prevail during warm periods off southeast Brazil. The Brazilian coastline in front of Cabo Frio City $\left(\mathrm{ca} .23^{\circ} \mathrm{S}\right)$ is characterized by an upwelling system, which propels the intrusion of nutrient-rich South Atlantic Central Water (SACW) over the shelf. The seasonal intrusion of SACW alters the MLD in this region and, therefore, may be an important feature that directly affects the depth behavior and preferences of sailfish. However, other oceanographic features have also been shown to affect the depth behavior of pelagic fishes. For example, Prince et al. (2010) and Stramma et al. (2012) demonstrated that the vertical distribution of sailfish and blue marlin was directly related to the amount of dissolved oxygen, which may act as a physical barrier to limit vertical movement (in the eastern Atlantic). However, considering the much higher concentrations of dissolved oxygen in the western Atlantic (Castro \& Miranda, 1998; Braga $\&$ Niencheski, 2006), such influence is unlikely in the present case.

The Brazilian pelagic tuna longline fleet is very diverse including national and chartered vessels with a complex targeting strategy (Carvalho et al., 2010; Mourato et al., 2011). Some inferences regarding changes in catchability may be drawn from the vertical distribution of sailfish. Based on our results, this species tends to spend much of the time in shallow surface waters. The average depth of the shallow-set longline used by the Brazilian longline fishery at nighttime targeting swordfish is ca. $50 \mathrm{~m}$ (B. Mourato, pers. commun.). Thus, it is very likely that sailfish vertical distribution is overlapping with the longline gear off the southeastern Brazilian coast. Though they apparently overlap with fishing gear, low catch rates of sailfish may be indicative of daytime feeding preferences. This information may be particularly useful to assist predictions for vertical distribution and relative abundance of sailfish through habitat-based stock assessments (Hinton \& Nakano, 1996; Brill \& Lutcavage, 2001). The lack of detailed knowledge on gear behavior (i.e., hook depths), however, would preclude the utilization of habitat-based standardization models in the southwestern Atlantic.

\section{Horizontal distribution}

In general, sailfish have probably one of the most restricted movement patterns of all istiophorid species in the Atlantic Ocean, as revealed by the recovery of conventionally tagged fish, with no trans-Atlantic, trans-equatorial, or intercontinental movements observed (Ortiz et al., 2003). However, significant movements were observed between the Straits of Florida and adjacent waters and between the Gulf of Mexico and the area near Cape Hatteras, North Carolina $\left(35^{\circ} \mathrm{N}\right)$ (Ortiz et al., 2003; Obersen et al., 2008). One of the main objectives of this study was to determine the summer residence and migratory route of sailfish during and after the spawning season off southeast Brazil. Unfortunately, the low number of tags deployed and low tag retention rates have left this question still unanswered. One sailfish tagged with a conventional tag was recaptured off the southeast Brazilian coast, very close to the tagging site, approximately one year after release and during the spawning period (Amorim et al., 2011).

Sailfish abundance in southeastern coast of Brazil is highly seasonal. This area represents an important spawning ground for the species (Mourato et al., 2009), which is related to the oceanographic conditions that prevail during warm season (Mourato et al., 2014). The Brazilian longline fleet operates south and southeast of Brazil and sailfish are incidentally caught all year-around, with the highest catches occurring from October to December. Also, there is a growing concern about the likely fisheries interaction with a developing local artisanal longline fishery that targets primarily mahi-mahi, (Coryphaena hippurus Linnaeus, 1758) and tunas. Sailfish comprises one of the most important incidental species caught by this fishery, and is subject to an unknown, but very likely high level of fishing mortality throughout the entire southeast Brazilian coast. Without government regulation, the fishing capacity of these artisanal and semi-industrial fleets has grown considerably. At present, the artisanal and industrial longline fishing fleets have conflicting interests with the sport fishing fleet regarding the equitable use of billfish resources. Hence, establishing precautionary billfish fishing practices and controlling exploitation to ensure the sustainable use of this resource in southeast Brazilian coast are urgent needs.

In conclusion, our results provide information into the biology of sailfish in the southwestern Atlantic and show how vertical distributions during the day and night are influenced by temperature. However, the basic lack of information about sailfish habitat use and fisheries interaction action (e.g., depth of fishing gear) persists but our study has provided initial information on sailfish vertical movement patterns in Brazil. Lastly, longer track durations, through international cooperative tagging projects, would be necessary to get a broader picture of residence times, exchange rates and migration corridors in the South Atlantic Ocean.

\section{Acknowledgments}

This study was funded by the Ministry of Fisheries and Aquaculture of Brazil (MPA). The senior author acknowledges receipt of a doctoral scholarship from the National Council for Scientific and Technological Development (CNPq, Brazil). We also thank Keith Bigelow for thoughtful comments and suggestions on earlier drafts of this paper. A portion of this study was completed by the senior author as a visiting scholar at the Joint Institute for Marine and Atmospheric Research (JIMAR, University of Hawaii).

\section{Literature Cited}

Amorim, A. F., E. G. Pimenta \& M. C. Amorim. 2011. Peixes de bico do Atlântico. Santos.

Beardsley, G. L, N. R. Merrett \& W. J. Richards. 1975. Synopsis of 
the biology of the sailfish, Istiophorus platypterus (Shaw and Nodder, 1971). Pp. 95-120. In: Shomura, R. S. \& F. Williams (Eds.). Proceedings of the International Billfish Symposium, Kailua-Kona, Hawaii, 9-12 August 1972. Part 3. Species synopses. NOAA Tech. Rep. NMFS SSRF 675.

Block, B. A. 1986. Structure of the brain and eye heater tissue in marlins, sailfish, and spearfishes. Journal of Morphology, 190: 169-189.

Block B. A., D. T. Booth \& F. G. Carey. 1992. Depth and temperature of the blue marlin, Makaira nigricans, observed by acoustic telemetry. Marine Biology, 114: 175-183.

Braga, E. S. \& L. F. H. Niencheski. 2006. Composição das massas de água e seus potenciais produtivos na área entre o Cabo de São Tomé (RJ) e o Chuí (RS). Pp.161-218. In: RossiWongtschowski, C. L. D. B. \& L. S. P. Madureira (Orgs.). O ambiente Oceanográfico da Plataforma Continental e do Talude Continental na Região Sudeste-Sul do Brasil, São Paulo, EDUSP.

Brill, R. W. \& M. E. Lutcavage. 2001. Understanding environmental influences on movements and depth distributions of tunas and billfishes can significantly improve population assessments. American Fisheries Society Symposium, 25: 179-198.

Brill, R. W., D. B. Holts, R. K. C. Chang, S. Sullivan, H. Dewar \& F. G. Carey. 1993. Vertical and horizontal movements of striped marlin (Tetrapturus audax) near the Hawaiian Islands, determined by ultrasonic telemetry, with simultaneous measurement of oceanic currents. Marine Biology, 117: 567574.

Carvalho, F. C., D. J. Murie, F. H. V. Hazin, H. G. Hazin, B. L. Mourato, P. Travassos, \& G. H. Burgess. 2010. Catch rates and size composition of blue sharks (Prionace glauca) caught by the Brazilian pelagic longline fleet in the southwestern Atlantic Ocean. Aquatic Living Resources, 23: 373-385.

Castro, B. M. \& L. B. Miranda. 1998. Physical oceanography of the western Atlantic continental shelf located between $4^{\circ} \mathrm{N}$ and $34^{\circ}$ S. Pp. 209-251. In: Robinson, A. R. \& K. H. Brink. The Sea, Vol. 11., New York, John Wiley.

Chiang, W. C., M. K. Musyl, C. L. Sun, S. Y. Chen, W. Y. Chen, D. C. Liu, W. C. Su, S. Z. Yeh, S. C. Fu \& T. L. Huang. 2011. Vertical and horizontal movements of sailfish (Istiophorus platypterus) near Taiwan determined using pop-up satellite tags. Journal of Experimental Marine Biology and Ecology, 397: 129-135.

Duffett-Smith, P. 1988. Practical Astronomy with Your Calculator. $3^{\text {rd }}$. Edition. Cambridge, Cambridge University Press.

Goodyear, C. P, J. Luo, E. D. Prince, J. P. Hoolihan, D. Snodgrass, E. S. Orbesen \& J. E. Serafy. 2008. Vertical habitat use of Atlantic blue marlin Makaira nigricans: interaction with pelagic longline gear. Marine Ecology Progress Series, 365: 233-245.

Graves, J. E., B. E. Luckhurst \& E. D. Prince. 2002. An evaluation of pop-up satellite tags for estimating postrelease survival of blue marlin (Makaira nigricans) from a recreational fishery. Fishery Bulletin, 100: 134-142.

Gunn, J. S., T. A. Patterson \& J. G. Pepperell. 2003. Short-term movement and behaviour of black marlin, Makaira indica in the Coral Sea as determined through a pop-up satellite archival tagging experiment. Marine Freshwater Research, 54: 515525.

Hinton, M. G. \& H. Nakano. 1996. Standardizing catch and effort statistics using physiological, ecological, or behavioral constraints and environmental data, with an application to blue marlin (Makaira nigricans) catch and effort data from the Japanese longline fisheries in the Pacific. Bulletin of the InterAmerican Tropical Tuna Commission 21: 171-200.
Holland, K., R. W. Brill \& R. K. C. Chang. 1990. Horizontal and vertical movements of Pacific blue marlin captured and released using sport fishing gear. Fishery Bulletin, 88: 397-402.

Holts, D. \& D. Bedford. 1990. Activity patterns of striped marlin in the southern California bight. Pp. 81-93. In: Stroud, R. S. (Ed.). Planning the future of billfishes. National Coalition for Marine Conservation, Inc., Savannah, Georgia.

Hoolihan, J. P. 2004. Horizontal and vertical movements of sailfish (Istiophorus platypterus) in the Arabian Gulf, determined by ultrasonic and pop-up satellite tagging. Marine Biology, 146: 1015-1029.

Hoolihan, J. P. \& J. Luo. 2007. Determining summer residence status and vertical habitat use of sailfish (Istiophorus platypterus) in the Arabian Gulf. ICES Journal of Marine Science, 64: 1-9.

Hoolihan, J. P., J. Luo, D. E. Richardson, D. Snodgrass, E. S. Orbesen \& E. D. Prince. 2009. Vertical movement rate estimates for Atlantic istiophorid billfishes derived from high resolution pop-up satellite archival data. Bulletin of Marine Science, 83: 257-264.

Hoolihan, J. P., J. Luo, C. P. Richardson, D. Goodyear, E. S. Orbesen \& E. D. Prince. 2011. Vertical habitat use of sailfish (Istiophorus platypterus) in the Atlantic and eastern Pacific, derived from pop-up satellite archival tag data. Fisheries Oceanography, 20: 192-205.

ICCAT. 2009. International Commission for the Conservation of Atlantic Tunas: Report of the 2009 sailfish assessment.

Jolley, J. W. \& E. W. Irby. 1979. Survival of tagged and released Atlantic sailfish (Istiophorus platypterus: Istiophoridae) determined with acoustic telemetry. Bulletin of Marine Science, 29: 155-169.

Kerstetter, D. W., S. M. Bayse \& J. L. Fenton. 2011. Sailfish Habitat Utilization and Vertical Movements in the Southern Gulf of Mexico and Florida Straits. Marine and Coastal Fisheries: Dynamics, Management, and Ecosystem Science, 3: 353-365.

Kerstetter, D. W. \& J. E. Graves. 2008. Postrelease survival of sailfish caught by commercial pelagic longline gear in the southern Gulf of Mexico. North American Journal of Fisheries Management, 28: 1578-1586.

Kerstetter, D. W., B. E. Luckhurst, E. D. Prince \& J. E. Graves. 2003. Use of pop-up satellite archival tags to demonstrate survival of blue marlin (Makaira nigricans) released from pelagic longline gear. Fisheries Bulletin, 101: 939-948.

Mourato, B. L., P. Pinheiro, F. H. V. Hazin, V. B. Melo, A. F. Amorim, E. Pimenta \& C. Guimarães. 2009. Preliminary analysis of gonadal development, spawning period, sex ratio and length at first sexual maturity of sailfish, Istiophorus platypterus in Brazilian coast. ICCAT, Collective Volume of Scientific Papers, 64: 1927-1940.

Mourato, B. L., C. A. Arfelli, A. F. Amorim, H. G. Hazin, F. C. Carvalho \& F. H. V. Hazin. 2011. Spatio-temporal distribution and target species in a longline fishery off the southeastern coast of Brazil. Brazilian Journal of Oceanography, 59: 185-194.

Mourato, B. L., F. Hazin, K. Bigelow, M. Musyl, F. Carvalho \& H. Hazin. 2014. Spatio-temporal trends of sailfish, Istiophorus platypterus catch rates in relation to spawning ground and environmental factors in the equatorial and southwestern Atlantic Ocean. Fisheries Oceanography, 23: 32-44.

Musyl, M. K., L. M. McNaughton. 2007. Report on pop-up satellite archival tag (PSAT) Operations, Conducted on Sailfish, Istiophorus platypterus by Research Scientists of the Fisheries Research Institute, Eastern Marine Biology Research Center, and Institute of Oceanography, College of Science, National Taiwan University, 6-7 June 2007, Chengkong, Taiwan. Available 
from: http://www.soest.hawaii.edu/PFRP/pdf/ Musyl\%20Taiwan\%20PSAT\%20report060707.pdf (28 Oct 2013).

Musyl, M. K., R. W. Brill, C. H. Boogs, D. S. Curran, T. K. Kazama \& M. P. Seki. 2003. Vertical movements of bigeye tuna (Thunnus obesus) associated with islands, buoys, and seamounts near the main Hawaiian Islands from archival tagging data. Fisheries Oceanography, 12: 152-169.

Musyl, M. K., R. W. Brill, D. S. Curran, L. M. McNaughton, B. Kikkawa, N. Fragoso \& C. D. Moyes. 2011a. Post-release survival, vertical movements and thermal niche partitioning in five species pelagic sharks released from longline fishing gear in the central Pacific Ocean. Fishery Bulletin, 109: 341-368.

Musyl, M. K., M. L. Domeier, N. Nasby-Lucas, R. W. Brill, L. M. McNaughton, J. Y. M. Swimmer, S. Lutcavage, S. G. Wilson, B. Galuardi \& J. B. Liddle. 2011b. Performance of pop-up satellite archival tags. Marine Ecology Progress Series, 433: 1-28.

Nakamura, I. 1985. FAO species catalogue. Vol. 5: Billfishes of the world. An annotated and illustrated catalogue of marlins, sailfishes, spearfishes and swordfishes known to date. FAO Fish Synop, Rome, n. 125.

Nielsen, A., K. Bigelow, M. Musyl \& J. Sibert. 2006. Improving light- based geolocation by including sea surface temperature. Fisheries Oceanography, 15: 314-325.

Orbesen, E. S., J. P. Hoolihan, J. E. Serafy, D. Snodgrass, E. M. Peel \& E. D. Prince. 2008. Transboundary movement of Atlantic istiophorid billfishes among international and U.S. domestic management areas inferred from mark-recapture studies. Marine Fisheries Review, 70: 14-23.

Ortiz, M., E. D. Prince, J. E. Serafy, D. B. Holts, K. B. Dary, J. G. Pepperell, M. B. Lowry \& J. C. Holdsworth. 2003. Global overview of the major constituent-based billfish tagging programs and their results since 1954. Marine Freshwater Research, 54: 489-507.

Peel, E., R. Nelson \& P. C. Goodyear. 2003. Managing Atlantic marlin as bycatch under ICCAT. The fork in the road: recovery or collapse. Marine Freshwater Research, 54: 575-584.
Pepperell, J. G. \& T. L. O. Davis. 1999. Post-release mortality of black marlin, Makaira indica, caught off the great barrier reef with sportfishing gear. Marine Biology, 135: 369-380.

Prince, E. D \& C. P. Goodyear. 2006. Hypoxia-based habitat compression of tropical pelagic fish. Fisheries Oceanography, 15: 451-464.

Prince, E. D., J. Luo, C. P. Goodyear, J. P. Hoolihan, D. Snodgrass, E. S. Orbesen, J. E. Serafy, M. Ortiz \& M. J. Schirripa. 2010. Ocean scale hypoxia-based habitat compression of Atlantic istiophorid billfishes. Fisheries Oceanography, 19: 448-462.

Restrepo, V., E. D. Prince, G. P. Scott \& Y. Uozumi. 2003. ICCAT stock assessments of Atlantic billfish. Marine Freshwater Research, 54: 361-367.

Sibert, J. R., M. K. Musyl \& R. W. Brill. 2003. Horizontal movements of bigeye tuna (Thunnus obesus) near Hawaii determined by Kalman filter analysis of archival tagging data. Fisheries Oceanography, 12: 141-151.

Stramma, L., E. D. Prince, S. Schmidtko, J. Luo, J. Hoolihan, M. Visbeck, D. W. R. Wallace, P. Brandt \& A. Kortzinger. 2012. Expansion of oxygen minimum zones may reduce available habitat for tropical pelagic fishes. Nature Climate Change, 2: 33-37.

Vaske-Junior, T. 2005. Cefalópodes oceânicos da zona econômica exclusiva do nordeste do Brasil. Boletim do Instituto de Pesca, São Paulo, 31: 137-146.

Vaske-Junior, T., C. M. Vooren \& R. P. T. Lessa. 2004. Feeding habits of four species of Istiophoridae (Pisces: Perciformes) from northeastern Brazil. Environmental Biology of Fishes, 70: 293-304.

Zar, J. H. 1996. Biostatistical Analysis, $3^{\text {rd }}$. ed. New Jersey: Prentice Hall.

Submitted June 21, 2013

Accepted May 3, 2014 by Francisco Gerson Araújo Published December 27, 2014 